\title{
THE BOY SCOUTS, CLASS AND MILITARISM IN RELATION TO BRITISH YOUTH MOVEMENTS 1908-1930*
}

In the 1960's academic attention became increasingly focused, in many cases of necessity, on the forms taken by student protest and, possibly in conjunction with this, there appeared almost simultaneously a corresponding upsurge of interest in the history of organized international youth movements, many of them with their origins in the late nineteenth or early twentieth centuries. ${ }^{1}$ Such a development in historiography would seem to contradict the statement once made by an English youth leader, Leslie Paul, that "because the apologetics of youth movements are callow, their arguments crude, and their practices puerile, they are dismissed or ignored by scholars." 2

It is certainly refreshing to see discussion of the Boy Scout movement rise above easy humour at the expense of Baden-Powell's more eccentric views on adolescent sex education. ${ }^{3}$ Yet despite the change in historical perspective, very little has been done until comparatively recently to place Scouting, as this article cautiously attempts to do,

* I would like to thank my colleagues - past and present - at the Lanchester Polytechnic, Coventry, and the New University of Ulster who commented on and made suggestions with regards to earlier drafts of this article. The faults and omissions are, of course, all my own.

1 Cf. A series of essays on "Generations in Conflict" published in: The Journal of Contemporary History, Vol. 4, No 2 (1969), and Vol. 5, No 1 (1970); Walter Z. Laqueur, Young Germany: A history of the German Youth Movement (London, 1962); Robert Hervet, Les Compagnons de France (Paris, 1965); Radomir Luza, History of the International Socialist Youth Movement (Leiden, 1970).

${ }^{2}$ Leslie Paul, Angry Young Man (London, 1951), p. 52. Paul was an Anglican philosopher who left the Scout movement on pacifist grounds, became a member of John Hargrave's Kibbo Kift, then founded in February 1925, at the age of 20, the Woodcraft Folk, a co-operative socialist co-educational youth movement which still survives in some parts of England.

${ }^{3}$ Cf. Norman Mackenzie, "Sweating it out with B-P", in: New Statesman, 15 October 1965. An article based on a flippant reading of Baden-Powell's Rovering to Success (1922) which does, however, make the valid point that Baden-Powell institutionalized adolescence in the Rover Scouts in order to hold off the realities of manhood. 
within the history of British society before the First World War. More of the folk-ways of Boer War England survive in the lore and language of the Boy Scouts than in almost any other contemporary British social institution whatever their recent attempts to move with the times. ${ }^{1}$

Perhaps it should be explained at the outset that this account of the Boy Scouts places the movement in an historical relationship with the other British youth movements in existence before 1914 and, moreover, implies that there was a constant interaction between them. It also offers an alternative analysis of their past to that which proclaims the almost total detachment of organized youth in Britain from politics or outside pressure groups. ${ }^{2}$ In order to look at the Boy Scouts against the social background of the 1900's, brief narratives of the historical origins of the other main British youth movements have been given followed by an investigation of their social compositions and power structures. Finally, certain conjectures are put forward which link the organizers of these movements with the imperialist, military and political élites of the Edwardian ruling class, as personified in an influential pressure group called the National Service League.

An underlying assumption of this analysis is that a knowledge of the mechanisms by which ruling adult groups legitimate their possession and exercise of power is of great assistance in interpreting the histories of British youth movements. By the notion of legitimation, I intend to define the means whereby a monopoly of domination is ensured to an authority by virtue of legality, tradition or charisma until, as Max Weber has indicated, the legitimacy of the authority becomes the legality of the general rule. ${ }^{3}$ It will further be argued that youth leaders

${ }^{1}$ In 1966 new, long-trousered uniforms were introduced and even the word "Boy" was dropped from Boy Scouts. There are still over half a million Scouts in Great Britain and nearly as many enrolled in the Girl Guides, while one in nine boys is a Wolf $\mathrm{Cub}$ : the junior branch of the Scouts which borrows many of its rituals from Rudyard Kipling. The 1971 census showed a total strength in Cubs, Scouts, Venture Scouts and adult leaders of 556,164.

2 Cf. Paul Wilkinson, "English Youth Movements, 1908-1930", in: The Journal of Contemporary History, Vol. 4, No 2 (1969), pp. 3-23. Referred to throughout as Wilkinson. This pioneering article has as a general thesis that: "the interesting thing about the English [youth] movements, in contrast to the continental, is why they did not become vehicles of overt political protest or instruments of party political manupulation." Ibid., p. 4. Whilst agreeing with him that they were not simply protest movements led by the young, this did not prevent them from becoming agencies of "protest", manipulated in the interests of social-political groups led by the old and middle aged, against the absence of compulsory military training for boys.

${ }^{3}$ Cf. for the sources of the notion of legitimation: Max Weber, The Theory of Social and Economic Orgnization (1947), parts 1 and 3, being part of his Wirt- 
like Baden-Powell strategically pre-empted certain cultural norms of legitimation in order to strengthen their power bases by manipulating the symbols of authority. As leader of the Boy Scout movement, BadenPowell had to defend his leadership against such charismatic secondin-commands as Sir Francis Vane, first Scout Commissioner for London in 1909, and John Hargrave, the Headquarters' Commissioner for Camping and Woodcraft, from 1916 to 1921.

Already several rather dubious historical "myths" surrounding the early lives of these movements have been successfully demolished - such as that ascribing the original "invention" of Scouting solely to Baden-Powell ${ }^{1}$ - but there still remain lacunae of misinterpretation that can now be reassessed on the basis of largely unconsulted documentary sources deposited at the headquarters of the surviving organizations. ${ }^{2}$ In the process, I shall re-examine several rather misleading but endurable orthodoxies which have accrued to the topic - such as that claiming social comprehensiveness and political internationalism for the Boy Scouts - although my main purpose is to make some tentative explorations of the social and political forces shaping the Boy Scout movement before 1930. But, before looking at the structural components of these different youth movements and their role in British social history, it may prove useful, for those unfamiliar with British experience, to disentangle their respective origins.

It is surely no coincidence that military-structured, organized youth emerged about the same time in British history as the New Imperialism of the late nineteenth century. If duty, honour and patriotism were the emotional moulds within which British imperial attitudes set, they also provided the mottoes of the new youth movements. Social organizations in uniform, from the Salvation Army to

schaft und Gesellschaft translated; H. H. Gerth and C. Wright Mills (Eds), From Max Weber: Essays in Sociology (London, 1967 ed.), pp. 78-79, 294-299; Irving L. Horowitz (Ed.), Power, Politics and People: the collected essays of C. Wright Mills (London, 1967), particularly the introduction by Horowitz.

1 Cf. Brian Morris, "Ernest Thompson Seton and the origins of the Woodcraft movement", in: The Journal of Contemporary History, Vol. 5, No 2 (1970), pp. 183-194, passim.

2 This article is largely based upon an examination of the archives held at the headquarters in London of the Church Lads Brigade, the Boys Brigade and the Scout Association. The correspondence between Sir Francis Fletcher Vane and Baden-Powell (1908-1914) and the Baden-Powell papers in the British Museum Mss Department have also been consulted. 
the Volunteers, were to become a familiar sight during a period in British history when both the social and military strands of the historical fabric were closely woven together. ${ }^{1}$ The resurgence of militarism and nationalism which accompanied British rivalry with Germany in the 1900's saw a tolerance towards military leadership of the young which was to be reversed during the bitter aftermath of the First World War. While in the atmosphere of the Edwardian era, military men like Baden-Powell were to profit from a climate of opinion favourable to any movement that seemed to strengthen imperial defences and efficiency to form uniformed youth movements for boys, in the 1920's waves of virulent pacifism and anti-militarism moved public opinion against the idea of ex-soldiers training the young.

The mass organization of the young outside of school by voluntary bodies began as a late nineteenth century phenomenon in Britain because earlier Victorian organizations, such as the Sunday School Unions, Bands of Hope Temperance Societies, and Young Men's Improvement Associations, were almost entirely concerned with religious and moral training within the framework of traditional Christianity. ${ }^{2}$ Although, as we shall see, they often provided the starting-off points for the new uniformed movements, the earlier institutions attracted only a limited Church going membership. Their successors, while still primarily religious in tone, used drill and military training in order to discipline and attract the young; this at once provided a reason for both their initial success and for much of the criticism levelled against them by anti-militarists.

Since the origins of the Boy Scouts in the 1900's would seem to owe more to the Boys Brigade than is usually accorded that body, it is worthwhile stressing at this point that the idea of producing a scheme of scouting which would appeal specifically to the young, based on his army manual Aids to Scouting for N.C.O.'s and Men (1900), did not come to Baden-Powell until after he had first made contact with the founder of the Boys Brigade. Before describing in more detail the setting up of the Boy Scouts, it might be useful to say something about its Victorian predecessor. Outsiders have often confused the Boys Brigade with the Salvation Army or the War Office but it was actually begun by

1 But cf. Olive Anderson, "The Growth of Christian Militarism in Mid-Victorian Britain", in: The English Historical Review, Vol. LXXXVI (Jan., 1971), pp. 46-72; which predates the idealization of the British soldier by the religious public to the period 1854 to 1865 .

${ }_{2}^{2}$ This does not, of course, apply to the boys' cadet companies started in the major public schools at the same time as the Volunteers (1859-1860) but not introduced into London working class districts by Toynbee Hall and Octavia Hill until the late 1880 's. 
a young Scotsman almost a quarter of a century before the formation of the Boy Scouts.

The Boys Brigade was a movement founded in 1883 among a group of unruly, teenage working class boys in Glasgow who attended the local Free College Church Sunday School run by William Alexander Smith (1854-1914), a deeply religious, strict disciplinarian who was both an officer in the first Lanarkshire Rifle Volunteers and an enthusiastic member of the Young Men's Christian Association. ${ }^{1}$ The idea behind the Brigade was to utilize Smith's military training in order to control the boys he taught on Sundays with elementary forms of drill, gym and team games added to their weekly religious instruction. This unique amalgam of militarism and evangelicalism proved so successful with the boys that Smith held meetings to popularize his scheme, after receiving reluctant permission from the Church, and had soon formed several companies in Glasgow alone. By 1891 the membership of the Brigade had risen to some 18,000 boys but with nearly two thirds of the membership in Scotland of which almost half were Scottish Presbyterian in religious composition. Despite the fact that there were over 8,000 boys in the London battallion by the outbreak of the First World War, the concentration of membership north of the border has remained a fairly constant factor in the history of the Boys Brigade. ${ }^{2}$

Initially, there was a great deal of vocal opposition from pacifists and some religious workers to the Brigade as a para-military force. They objected to the use of drill and dummy rifles (not abolished until 1924) which were seen as encouraging the "military spirit" among boys. Both the International Arbitration League and the Peace Society attacked the Brigade for using military terms and titles that were all directly imitative of Army usage. Christianity and militarism were supposedly incompatible. ${ }^{3}$ Youth workers objected to the element of

1 Smith was born near Thurso in 1854. His father died in 1867 and his uncle took him into his warehouse as a clerk when he was barely 15. At Glasgow he went with his uncle to the Free College Church and "sat under" the Rev. George Reith, father of Lord Reith the first Director-General of the BBC, who backed young Smith's ideas enthusiastically and was Chaplain of the First Company of the Boys Brigade from its formation until his death in 1919.

2 Secondary sources for the Boys Brigade include: Austin E. Birch, The Story of the Boys Brigade (London, 1959); F. P. Gibbon, William Smith and the Boys Brigade (London, 1934); R. S. Peacock, Pioneer of Boyhood: The story of W. A. Smith (Glasgow, 1954). More useful are early issues of: The Boys Brigade Gazette and The Brigadier.

${ }^{3}$ Cf. Samuel Milliken, Christian Soldiers (London, 1907). This was a leaflet issued by the International Arbitration League; it was a reprint of an article hostile to the Brigade that first appeared in the New York Evening Post. Copies could be obtained from Sir Randall Cremer, a well known pacifist MP, at the League's offices for $6 \mathrm{~d}$. per 100 . 
compulsory drill and Bible reading in the Brigade, since it narrowed working class recruitment, or to poor management and lack of permanent accommodation, but these were usually advocates of Working Boys' Clubs with an axe to grind. ${ }^{1}$

Significantly, another new movement, the Boys Life Brigade, was started in Nottingham in 1899, on the outbreak of the Boer War, by the Rev. John Brown Paton, in reaction to the antagonism which Smith's military methods had aroused among some Churchmen. The inter-action between the youth movements is brought out by the involvement of Paton with both the National Sunday School Union and several Boys Brigade companies in Nottingham and Rugby. Life saving drill was to be used to give the obedience and discipline which Smith derived from military drill but without the overtones of jingoism that clung to the Boys Brigade at this time. By 1906 over 8,000 boys belonged to the Life Brigade whose drill manual included: marching, gym, stretcher drill and life saving instruction. ${ }^{2}$ Ironically, it merged with the Boys Brigade twenty years later.

The role of Smith and the Boys Brigade in the genesis of the Boy Scouts is clarified by a chronology of the events leading up to the formation of the latter which reveals Baden-Powell's self-confessed indebtedness to Smith for his eventual world fame. The Chief Scout began life as a young hussars officer, like another famous Englishman, Sir Winston Churchill, whom he met briefly while serving on the North West Frontier of India. ${ }^{3}$ After over twenty years spent fighting and spying in a variety of colonial wars, Baden-Powell won the attention of the British public during the Boer War siege of Mafeking which he used to demonstrate his resourcefulness while at the same time ad-

${ }^{1}$ Cf. B. Paul Neuman, The Boys' Club: in theory and practice. A manual of suggestions for workers (London, 1900), pp. 28-42; C. E. B. Russell and I. M. Rigby, Working Lads' Clubs (London, 1908) pp. 329-330. Company parades in the Glasgow of the 1880's were subject to their share of abuse and rough treatment from the local "hooligans", who found the Brigade's familiar uniform of pill-box hat, belt and haversack a conspicuous target which even inspired a popular ditty: "Here comes the Boys Brigade / All smovered in marmalade / A tup'ny 'appenny pill-box / And 'arf a yard of braid."

2 Boys Life Brigade, Code of Rules and Regulations (London, 1900), British Museum. Cf. John Lewis Paton, John Brown Paton: a biography by his son (London, 1914). Paton also started the patriotic Boys' League of Honour.

${ }^{3}$ Baden-Powell believed as a young man that the British were fortunate in having "a valuable training ground for our officers in the North West Frontier of India, with real live enemies always ready to oblige in giving us practical instruction in the field". Baden-Powell, Indian Memories (London, 1915), p. 205. 
vancing his career. ${ }^{1}$ Mafeking was relieved on 18 May 1900 and BadenPowell was made the youngest Major-General in the Army. After the war was over, he was left in virtual semi-retirement at the age of 46 but whether this was more because of the absence of colonial wars to fight in than a result of the general dislike of bureaucratic military machines for egregious soldiers is open to interpretation. Baden-Powell's military duties were confined to visiting cavalry schools, attending manoeuvres throughout Europe and writing a manual on cavalry training for Lord Roberts. It should be mentioned that one of his early biographers has argued that this work in cavalry training made Baden-Powell part of the "great forward movement" in Army reform. ${ }^{2}$

The idea of using his spare time to draw up a scheme of scouting which would attract the young first came to Baden-Powell, as already indicated, through his contact with the Boys Brigade of which he had become a Vice-President in 1902. In May 1903, Baden-Powell took the chair at the annual Albert Hall Boys Brigade demonstration and a year later he reviewed them in Glasgow, again at the request of their founder, W. A. Smith. Although Baden-Powell was certainly impressed with what he saw, when Smith told him that there were now about 54,000 boys in the Brigade, he could not help adding that "considering the number of boys available in the country, there ought, in the space of twenty years, to be ten times that number in the ranks, if the programme offered them were sufficiently varied and tempting."3 When asked how he would set about the task, Baden-Powell suggested some form of scouting, which had proved so popular with young soldiers in the cavalry. Smith concurred and told the hero of Mafeking to rewrite his army manual in a form that could be applied to the training of boys. Thus, the youth movement which was soon to dwarf the Boys Brigade owed its original instigation to the Brigade's founder.

Initially, Baden-Powell had no intention of setting up a "separatist" movement. In a memorandum of October 1908 he wrote that:

"the development of the scheme of Boy Scouts has assumed very large proportions and has gone beyond what had been expected in

\footnotetext{
1 Baden-Powell was ordered out to South Africa on special service to raise two battallions of Mounted Rifles and to organize the Cape Colony Police forces. Despite the mobility of his men and General Wolseley's instructions that they were to be used to defend the borders, he allowed himself to be pinned down by the Boer General Cronjé at Mafeking, where they were besieged. For a revealing discussion of the orders Baden-Powell received from Wolseley see: Brian Gardner, Mafeking: A Victorian Legend (London, 1966), pp. 35-37

2 R. H. Kierman, Baden-Powell (London, 1939), pp. 181-182.

${ }^{3}$ Quoted in: Henry Collis, Fred Hurll and Rex Hazlewood, B-P's Scouts: An official history of the Boy Scouts Association (London, 1961), p. 25.
} 
its first initiation six months ago. It was started with the idea that its chief points might form useful additions to the present attractions or training held out to boys by the different organizations, such as the Boys Brigades, Y.M.C.A., Boys' Clubs etc., but it has been found in practice that a large number of lads have preferred to band themselves together as Scouts, independent of existing organizations."1

It is clear that originally Baden-Powell had hoped to amalgamate Scouting with the Brigades but because Smith was afraid that this would change the character of his movement too drastically he demurred and in December 1909 he even turned down an offer to sit on the Boy Scout Advisory Council. The setting up of the Incorporated Church Scout Patrols in 1908, run by the Church Lads Brigade until affiliation to the Boy Scouts in $1914,{ }^{2}$ followed the more calculating Anglican policy of accommodation to changing trends; but Smith remained proudly resistant to any watering down of his original concept.

In 1905 Baden-Powell visited several Boys Brigade regiments in England and Wales, while still carrying out his official duties as Inspector General of British Cavalry. The preliminary proposals for the organization of the Boy Scouts were first published, indicatively, in the 1 June 1906 issue of the Boys Brigade Gazette, with an introduction by W. A. Smith, several months before Baden-Powell was to meet his American counter-part, Ernest Thompson Seton. Then, from 14 to 16 July, Baden-Powell went to stay with Arthur Pearson, the Tory newspaper proprietor of the pro-Tariff Reform Daily Express, at his country house in Frensham, Surrey, to talk over the idea of scouting for boys. On 30 October 1906, he met Seton at the Savoy Hotel, London, and confirmed the discovery that the two men had, completely independently of each other, evolved similar schemes for the training of the young on a "woodcraft" basis: as Brian Morris points out, the Boy Scout movement which eventually emerged was as much the "product of an era" as it was of any one man. Even at this stage, it is possible to predict the rift which later occurred between them: for while Baden-Powell referred in his articles to patriotism and "good

${ }^{1}$ Quoted in: E. K. Wade, Twenty One Years of Scouting (London, 1929), p. 78 . 2 The Church Lads Brigade Scout Patrols sometimes offered rather intemperate advice, e.g., "Here at home, if you ever hear a boy crying down his country or telling lies about the King, tell him to shut up, and if he won't then punch his head." From: Scout Law No 2, in: The Incorporated Church Scout Patrols Scout Message, Vol. II (September, 1911), p. 6. 
citizenship" as being the goal of the Boy Scouts, Seton aimed only to promote a scheme of education in outdoor life through his American Woodcraft Indians. ${ }^{1}$

These interviews and meetings of 1906 all formed part of the gestation process of the famous Scout handbook Scouting for Boys. By the beginning of 1907 Baden-Powell had prepared a draft outline scheme which he sent to a few friends, including Smith, in February. This was published in a slightly revised form in May as Boy Scouts - A Suggestion and, together with a leaflet of explanation, distributed throughout the country. ${ }^{2}$ Baden-Powell's diary shows that on 19 June 1907 he spent nine hours writing the handbook at the Mill House next to the windmill which still survives on Wimbledon Common, South West London completing what was to become the bible of the movement from December 1907 to January 1908. The historic first experimental Scout camp was held on Brownsea Island in Poole harbour, Dorset, from 29 July to 9 August 1907: most of the 20 boys present being supplied from the Boys Brigade in Poole and Bournemouth. ${ }^{3}$

On 23 October 1907, Harold Cox had agreed to publish Scouting for Boys in six fortnightly parts at $4 \mathrm{~d}$. a copy beginning on 15 January $1908 .{ }^{4}$ So great was the handbook's success that The Scout, a weekly penny newspaper aimed at the fourteen to twenty five age group, also appeared from 14 April 1908, with a weekly circulation in its first year of 110,000 copies. The advertising claimed that it would "appeal to the Imperialistic spirit of the young men of Great Britain" and would educate them in their future responsibilities as citizens. In this context, it is interesting to speculate on the future of the scheme had Arthur Pearson not dissuaded Baden-Powell from adopting the name Imperial Scouts to christen the new movement because it resembled the senescent Imperial Legion of Frontiersmen. ${ }^{5}$

1 Seton was eventually ousted from the American Scout Council in February 1915 for criticizing the nationalism behind the movement as it had been developed by Baden-Powell in England. Cf. Brian Morris, op. cit., pp. 186-188.

2 These two historical documents are reprinted in full in: E. E. Reynolds, The Scout Movement (London, 1950), pp. 9-13.

3 Sources for Brownsea Island include: Baden-Powell's diary, Baden-Powell Add. Mss 50255, British Museum; BBC 1, TV, 4 August 1967, “The Scouts' Jubilee: Report from Brownsea Island"; Reynolds, op. cit., pp. 21-22; Wade, op. cit., pp. 45-51.

4 For the localized impact of the part-form publication: cf. Capt. Colbron Pearse, "Records of the 1st. Hampstead Troop", in: The First's Own, Vol. 1, No 1 (1 Nov., 1910), p. 9; Iola [pseudon.], "Our History”, in: The First North London Troop Magazine, Vol. 1, No 1 (Nov., 1911), n.p., British Museum.

${ }^{5}$ Cf. E. K. Wade, op. cit., pp. 52-53. 
There remains a general impression that the Boy Scouts appeared spontaneously to fill up a social vacuum created by the absence of "outdoor" movements in Britain which can be slightly misleading, as it tends to obscure both the camping activities of the Church Brigades and the propaganda impact made on public opinion by Baden-Powell's numerous publications and the frequent lecture tours which he embarked upon specifically to promote the growing movement. A great deal of financial support was also received from both Pearson and the Daily Telegraph which made possible the publicity necessary to launch such a revolutionary new youth movement. ${ }^{1}$ The first really big Boy Scout rally, of 11,000 Boy Scouts, was held at the Crystal Palace in September 1909 and three months later an Advisory Council and an Executive Committee were formed but it was not until 4 January 1912 that the Scouts received their Royal Charter of Incorporation.

Meanwhile, early in 1908, Baden-Powell had been appointed General Officer Commanding of the Northumberland Territorial Division, a post he held until resigning from the Army in 1910 and joining the Reserve. This post allowed him ample time for organizing the Boy Scouts but it also had the unfortunate effect of associating him in the "public mind" with the Territorials: set up by his friend R. B. Haldane, the British War Minister, in 1907 to replace the superannuated Volunteers. Consequently, the Boy Scouts were seen by Baden-Powell's detractors - always in a small minority - as being introduced to provide a pool of recruitment for the Territorials. Liberals critical of the militarist character of the Scouts and the impetus given to army recruitment by the Chief Scout would have found some confirmation of their suspicions if they had happened to obtain a copy of The Patriot, the Essex branch magazine of the National Service League, in which the Secretary of the West Essex Scouts wrote that:

"the large number of old scouts joining the Territorial force is also a satisfactory feature [of progress]. In one year one troop alone supplied thirteen Territorial recruits. As there are 300,000 [sic]

1 The Daily Telegraph organized appeals that brought in $£ 6,000$ in 1909 and over $£ 10,000$ in 1910 , as well as giving $£ 4,000$ a year towards the cost of upkeep for the new Headquarters; Pearson provided an office for the movement and gave $£ 1,000$ to cover their initial expenses, as well as publishing The Scout and the cheaper edition of the handbook. Lord Strathcona gave a donation of $£ 500$ to Headquarters. Baden-Powell gave lectures on Scouting all over Britain, from November to December 1907, at meetings organized by the YMCA, which were repeated in 1908 to boost the sales of the cheap edition of Scouting for Boys published by Arthur Pearson. And from 28 May 1908 the Chief Scout took a scout patrol from London on a tour of the provinces to demonstrate "Scoutcraft". 
Scouts in the country, the organization is a possible recruiting ground by no means to be despised."1

If positive encouragement had been given by many Scoutmasters to potential recruits for the Territorials it would have been hardly surprising considering that about two thirds of the early Commissioners and Presidents were retired colonels and majors not adverse to supporting this trend among officers in the lower echelons of the hierarchy. Baden-Powell's critics would also have been dismayed if they had heard his speeches to such organizations as the National Defence Association or the Royal United Services Institute, on Scouting as a way of training youth in the character required for national defence. $^{2}$

While setting up the movement, in May 1908, Baden-Powell had given a much publicized lecture to his Territorial officers in Newcastle which ill-advisedly referred to Germany as "the natural enemy of this country" and served to identify the Boy Scouts with militarism at an early stage in their career. ${ }^{3}$ Questions were asked in the House of Commons and there was "a general feeling that the Scouts were training for war"4 which could not have been appeased by the references scattered throughout the handbook to the need for military preparation in case of an invasion; encapsulated by the demand that "every boy should prepare himself, by learning how to shoot and drill, to take his share in the defence of the Empire".5 Baden-Powell's approach to imperial and national problems was basically that of an ex-soldier: his solutions tended to be military rather than political or economic. Scouting for Boys contains much advice on the best way for the young to equip themselves for imperial defence without mentioning either imperial preference - his friend Arthur Pearson was, after all,

1 The Patriot, Vol. III (October, 1910), p. 6. His estimate triples the number of Scouts then in existence.

${ }^{2}$ Cf. A paper read on 6 May 1910, in: National Defence, Vol. 4, No 17 (August, 1910), pp. 434-447; on 29 March 1911, Baden-Powell gave a lecture to the RUSI on the Boy Scouts in connection with national training and national service; his friend R. B. Haldane, Secretary of State for War, was in the Chair: Royal United Services Institute Journal, Vol. 55 (Jan.-June, 1911), pp. 581-599.

3 Baden-Powell saw Germany in this prescient role because she "wanted to develop her trade and commerce, and must, therefore, get rid of England, which blocked the way." The Newcastle Daily Chronicle, 4 May 1908.

${ }^{4}$ I. O. Evans, Woodcraft and World Service (London, 1930), p. 32. Cf. Great Britain, Parliamentary Debates (Commons), 4th ser., Vol. CLXXXVIII, 13 May, 1908, cols 1122-1123.

5 Baden-Powell, Scouting for Boys (London, 1908), p. 314. All references are to the edition published in six fortnightly parts by Horace Cox not to the cheap edition published by Arthur Pearson. 
the Chairman of the Tariff Reform League - or imperial federation. The ideology under-pinning Scouting was a combination of BadenPowell's own personalized brand of social-imperialism, an omnipresent social darwinism and the Edwardian cult of national efficiency.

What Arthur Marwick once called "Baden-Powell's Edwardian zeal in preparing the armies of the future"1 had its origins in the military weaknesses which the disastrous South African War had revealed in the British Empire, the contemporary concern for standards of national efficiency and physical health, and a soldier's fears of unchecked German naval expansion. Interestingly, Baden-Powell gained much of his inspiration from an anonymous pamphlet published in 1905 which drew an analogy, for satirical purposes, between the decline and fall of the Roman and British Empires: largely in terms of their inability to defend themselves. ${ }^{2}$ The fall of the Roman Empire, according to Baden-Powell's diagnosis, was due to bad citizenship, and "the same causes which brought about the fall of the Great Roman Empire are working today in Great Britain". ${ }^{3}$ To avert this calamity, his prescription included training the younger generation to shoulder the responsibilities and duties of Empire through a movement such as Scouting.

Despite Baden-Powell's earlier protestations to W. A. Smith that he did not intend to form a separate organization, it had become obvious, as early as the summer of 1907 (at the same time as he had been placed on half-pay as a Lieutenant Colonel), that the enthusiasm which he had generated made it technically impossible for Scouting to remain a mere ancillary to the Boys Brigade. By 1910 there were over 100,000 Boy Scouts: totalling more than the combined memberships of the Boys Brigade and the Church Lads Brigade. In only a few years, Scouting had germinated from an idea suggested by Smith at a Boys Brigade demonstration into a national movement, outstripping in numbers all its nearest rivals. Although it has been suggested that Baden-Powell saw his scheme primarily as a contribution to the more effective maintenance of the British Empire, it would be a

1 Arthur Marwick, "Youth in Britain, 1920-1960: Detachment and Commitment", in: The Journal of Contemporary History, Vol. 5, No 1 (1970), p. 44.

2 Anon. [Elliot E. Mills], The Decline and Fall of the British Empire (Oxford, 1905). Mills was a National Service League supporter. His pamphlet gave BadenPowell the final words of his text to instructors published separately as a $2 \mathrm{~d}$. leaflet in 1907 which formed the last chapter of Scouting for Boys. It may also have provided Baden-Powell with his favourite parallel between the Roman crowds at circuses and British crowds flocking to watch paid professional footballers.

3 Baden-Powell, op. cit., p. 335. 
disservice to his memory to ignore both the grass-roots appeal of the movement and Baden-Powell's genuine desire to share the open-air life with those less fortunate in their social and family background than himself.

\section{II}

Since, as C. Wright Mills assured us, power functions as an independent social variable, it will prove instructive to take up a recent recommendation that the historian can gain some indication of the attitude of military and political elites towards Scouting through an examination of the composition of the first Executive Committee of the Boy Scout Governing Council. ${ }^{1}$ Half of the Committee's members were serving or retired Army officers with shared combat experience in India or the South African wars. Two of them were prominent members of the National Service League (1902-1921): a militant extra-parliamentary pressure group dedicated to the introduction of conscription into Britain, that raised fears of a German invasion and demanded the compulsory military training of the young. ${ }^{2}$ The liberal aristocrat Sir Francis Vane, ${ }^{3}$ appointed Scout Commissioner for London by Baden-Powell in June 1909, complained that "when the Scout Council was created all the chiefs of the National Service League were brought in."4

${ }^{1}$ Cf. Wilkinson, op, cit., p. 14.

2 Cf. Denis Hayes, Conscription Conflict: The conflict of ideas in the struggle for and against military conscription in Britain between 1901 and 1939 (London, 1949). Written over twenty years ago this is still the only substantial published work that deals with the League in any detail. The members of the National Service League on the Executive Committee of the Boy Scout Governing Council were: Colonel H. S. Brownrigg and Sir Edmund Elles. The other military members were: Colonel Ulick de Burgh, Deputy Chief Commissioner at Scout Headquarters, General Sir Herbert Plumer, Vice-Chairman of the Executive Committee, and Baden-Powell its Chairman. In 1921 the League was wound up, handing over its assets of $£ 12,000$ to Boy Scout Headquarters as being the body which most "successfully teaches the ideals of citizenship of which Lord Roberts' scheme was a part". Lord Milner quoted in: The Irish Scouts Gazette, No 10 (February, 1921), n.p.

3 For biographical details see: 'Agin the Goverments (London, 1929), whose title accurately reflects his career. For his ideas: the pamphlets, On Certain Fundamentals (London, 1909) and The Other Illusions (London, 1914). Vane was accused of pro-Boer sympathies by his enemies after writing Pax Britannica in South Africa (London, 1905): a courageous indictment of British treatment of Boer civilians. Sir Francis was a curious figure who cast himself in the role of a knight errant but like Don Quixote often tilted merely at windmills.

- Vane to F. W. Pixley, 17 October 1910, British Boy Scouts Folder 2, Scout Association, London. Vane wrote to Baden-Powell that he "very much deplored 
To idealists like Vane, executive control of the young movement appeared to rest entirely in the hands of soldiers or conscriptionists possessing goals sharply at variance with Thompson Seton's open-air woodcraft philosophy. Already, in October 1909, Lieutenant-General Sir Edmund Elles, ${ }^{1}$ one of the most influential of the British militarists, had been appointed Chief Scout Commissioner by Baden-Powell, an office which he held until 1922. Vane, in a self-justifying account of the events leading up to his dismissal from the movement, quotes Elles as remarking that his object in joining was to help further the military ideal and that "his only interest in the Scouts was for the purpose of getting recruits for the Territorials"; Vane saw himself as being suddenly placed "under the direct orders of an officer who only thought of war". ${ }^{2}$ For the historian of British youth movements, the acrimonious correspondence between Sir Francis Vane and Baden-Powell not only provides revealing insights into the conflicts of leadership within an Edwardian youth movement but also brings to the surface the continuous internal debate over the alleged militarism of the BadenPowell Boy Scouts.

Moving on to the class composition of the movement, an investigation of the social backgrounds of the Boy Scouts themselves would seem to suggest, on the available evidence, that the majority of the early members came from a middle or lower middle class rather than a working class environment. This hypothesis, tested against historical data, has recently been fully reinforced by a more modern social survey conducted by Mass Observation. ${ }^{3}$ What little empirical research the

the introduction into it [the Scout Council] of men who had been foremost in attempting to induce the English people to accept universal military training", moreover he was convinced that "the advent of these officers would, as in effect it did, give the movement a military direction". Vane to Baden-Powell, 4 June 1910 , ibid. Vane was referring to the induction into the movement in December 1909 of: the Earl of Meath, both a Vice-President and on the Executive Committee of the National Service League; Lord Charles Beresford a "hard-line" navalist and Field-Marshal Earl Roberts ("Bobs") who was actually the President of the League. In 1911 Lord Kitchener joined the Scout Council.

1 Elles was an old Indian "hand" and like the Chief Scout had been made a Major-General during the Boer War; from 1901 to 1905 he sat as a Military Member on the Governor-General's Council in India. On retirement from active service in 1908, he became Chairman of the Surrey County Territorial Force Association for twenty years and also sat on the National Council of the Territorials. Elles was a member of the Executive Committees of both the National Service League and the Scout Governing Council before 1914.

2 Vane, 'Agin the Governments (London, 1929), p. 210.

${ }^{3}$ In the Spring of 1966, the Baden-Powell Scout Guild commissioned Mass Observation to carry out a survey, using a nationally representative sample of 2,000 adults, which found that $44 \%$ of the middle classes among those inter- 
present author has been able to do shows that, for the 1920's at least, the South Eastern Home Counties of England, with a larger statistical proportion of middle income families than further north, ${ }^{1}$ had the highest density of Boy Scouts in relation to their age group rather than in relation to the more impressive but less significant statistical factor of the total number of Boy Scouts per county. Thus although the populous West Riding of Yorkshire had over 7,000 Scouts in 1921, in terms of density for the 300,000 boys in the 10 to 19 age group, it had a ratio of only 25.6 per 1,000 while Hertfordshire in the South had 75 per 1,000. Similarly, Lancashire had nearly 18,000 Scouts but only 38.9 per 1,000 while Cambridgeshire, with under a 1,000 Boy Scouts, had a density of 82.8 : simply because there were only about 11,000 boys in the 10 to 19 age group in this particular county. It would be fair to state that the predominantly more middle and lower middle class Home Counties around London had a higher density of Boy Scouts per 1,000 of the teenage group in the 1920's than the more working class, industrial centres of Yorkshire and Lancashire. ${ }^{2}$ In other words, a middle class boy of 14 living in the South East of England was far more likely to join the Boy Scouts than his working class equivalent in the North of England or Scotland.

Further evidence of the "bourgeois" social composition of the Boy Scouts was supplied by Baden-Powell in 1910 when he was reluctantly persuaded to confess, to a meeting of the National Defense Association, that Scouting made more of an appeal to the lower middle classes than to the working classes: especially in London, Edinburgh and Aberdeen, although not in the Boys Brigade stronghold of Glasgow. There were, at this time, about 11,000 Scouts in London alone and he calculated that about half or more of them came from the lower middle class and

viewed had been Boy Scouts but only $25 \%$ of the working classes had joined. Those in the middle classes also tended to stay in for longer than those in the working classes and Scouting appeared to be more popular in the South of England than in the North. (Statistics showing parental occupations of Boy Scouts are not kept by the Scout Association and early warrants issued to Scoutmasters have already been destroyed.)

1 Between 1949 and 1964 earned income, as measured by Schedule E income tax returns, increased in relation to the national average by more than $3 \%$ in South East England and the Midlands while declining by more than $3 \%$ in the North of England and Scotland. Cf. E. M. Rawstron and B. E. Coates, Variations in Britain: Studies in economic and social geography (London, 1971).

2 These figures were reached by using the 1921 Census of England and Wales and the relevant Boy Scout Annual Reports to calculate approximate densities. Using these results it proved possible to draw up distribution maps showing both the total number of Boy Scouts in each county for 1921 and the total number of Scouts per 1,000 of the 10 to 19 age group for this census. 
the rest from the "lowest class". ${ }^{1}$ It would, perhaps, be an interesting exercise to discover how many of these lower middle class Boy Scouts in later life joined one of the several British fascist organizations that proliferated in the 1920's and 1930's since their geographical and social recruitment corresponds so closely to that of the Boy Scouts. ${ }^{2}$

Working from these assumptions, what then are the social and historical reasons for the much greater propensity of Boy Scouts to come from middle or lower middle class rather than from working class homes? After all, one of Baden-Powell's declared aims in starting Scout troops had been that "the most important work that the Scout movement can do lies in getting hold of the vast hordes of slum boys in the great industrial centres of the North Midlands." 3 Why then did the Boy Scouts fail to achieve this potential objective? There are basically two types of answer to the interesting historical problem of trying to explain Scouting's narrow base of class recruitment: financial and ideological. The former does not concern us here, except to say that the prohibitive cost of the Scout uniform and Baden-Powell's constant exhortations on the subject of thrift, acted as obstacles which effectively deterred much potential working class support from the movement. ${ }^{4}$

On the ideological front, the chief deterrents to working class membership, assuming they could afford to join, were the general rules encouraging regular Church or Chapel attendance ${ }^{5}$ - working class boys

1 Baden-Powell in: National Defence, op. cit., p. 447. Baden-Powell tended to confuse the issue when talking about social class as he would frequently make moral value judgements, e.g., "In Edinburgh they are very good class as a rule; in Glasgow they are the worst class." Ibid.

2 Cf. R. B. D. Blakeney, "British Fascism", in: The Nineteenth Century, Vol. XCVII, No 575 (Jan., 1925), pp. 132-141: in which the President of the first fascist organization in Britain, largely run by ex-generals, claimed rather spuriously that Fascism was "the adult growth" of the Scout Movement. I am grateful to my colleague Iain Hutchison for drawing my attention to this reference.

3 Baden-Powell to E. K. Wade. 25 November 1910, Baden-Powell Add. Mss 50255, British Museum. Pencilled correction in this diary replaces "North Midlands" by "the country".

4 One Scoutmaster admitted that it had "proved difficult to bring the poorest class of boy into touch with Scouting, owing in great part to the expense [approx. 10 shillings] of the uniform." Jerrold W.Law, "Scouting and the Workhouse Boy", in: The Headquarters Gazette, 14 November 1911, p. 23. The Ninth Scout Law strongly encouraged saving: Baden-Powell demanded as an incentive that every new Scout opened a banking account or had a savings bank balance of at least a shilling. Cf. Baden-Powell, The Young Knights of the Empire (London, 1916), pp. 72-79.

- Baden-Powell declared in Scouting for Boys that: "No man is much good unless he believes in God and obeys His laws. So every Scout should have a 
were far more likely to prefer a non-denominational Working Boys' Club - and the persistent British working class tradition of resistance to any form of organized militarism. ${ }^{1}$ Many industrial workers, especially coal miners, associated uniformed youth movements with army recruitment: this historical antipathy was particularly strong in nonconformist South Wales, and the industrial areas of Yorkshire and the East Midlands, as evidenced by the unpopularity of the various Brigades in these regions. ${ }^{2}$ Even the leaders of the Labour Party in the House of Commons shared the common working class identification of Scouting with militarism. For example, in 1923 Baden-Powell tried to get Labour more fully represented on the General Council of the Boy Scouts Association. Ramsay MacDonald, soon to become Labour's first Prime Minister, cautiously refused to participate since, as he put it in a letter to the Chief Scout:

"A warm controversy is going on at present amongst my friends as to whether it [the Boy Scouts] is not being militarized, and whether as a matter of fact it is not under the effective control of masters who mean quite definitely that it should be so. [...] If, however, I agreed with your proposal, it would be adding one more internal trouble to what is my chief concern at the moment, the Labour Party. Nothing would justify that."3

religion." The rules of the movement "expected that every Scout shall belong to some religious denomination and attend its services." Scout Troop Church parades were also a frequent activity for Boy Scouts. Cf. E. K. Wade, op. cit., pp. 62 and 93.

1 Before 1933, the Hitler Youth in Germany had to cope with the same problem. Contrary to the SA, the Hitler Youth never managed to win over parts of the working class even during the years of the economic depression. Cf. HansChristian Brandenburg, Die Geschichte der HJ. Wege und Irrwege einer Generation, Verlag Wissenschaft und Politik (Cologne, 1968), passim. I am grateful for this reference to A. V. N. van Woerden, Editorial Secretary of this journal. Walter Laqueur suggests that a fairly high proportion of Hitler Youth may have come from lower-middle-class families who had been "proletarianized" during the years of inflation and economic crisis in Germany: Laqueur, Young Germany (London, 1962), p. 195, fn. 1.

2 One sensitive chaplain in a northern industrial centre was convinced that the local coal-miners saw his Church Lads Brigade cadet company as a recruiting trick for the Army and an insidious way of instilling militarism into their boys: "In common with other industrial centres, it was not long before the company was up against the bogey of militarism. I knew how strong the local feeling was and I anticipated the accusation as soon as the fact of the company's existence became generally known." Rev. Edgar Rogers, The Making of a Man in the Church Lads Brigade (London, 1919), p. 72.

${ }^{3}$ Quoted in: E. E. Reynolds, Baden-Powell: A Biography (London, 1942), p. 215. 
George Lansbury, the veteran pacifist Labour spokesman who replaced MacDonald as Leader of the party in 1931, declined Baden-Powell's offer in a similar vein on 4 July 1923, pointing out that "there always seems to me so much of patriotism and Union Jack flying, that I am somehow choked off from it."' The view that only a minority on the extreme left showed real hostility to Scouting in the inter-war years would seem to be jeopardized by these refusals; both the Independent Labour Party and the Labour Party passed resolutions at their annual conferences in the 1920's condemning militarism in education and youth movements. ${ }^{2}$

\section{III}

An even more striking illustration of the sensitivity of the working classes towards the military training of the young during this period is provided by the attention shown towards their feelings during the internally momentous events from 1910 to 1911, which transformed the Church Lads Brigade into a militarized cadet movement. The Church Lads Brigade was begun in 1891, as an anglicized version of the Boys Brigade, after a proposal by Walter Mallock Gee, Secretary of the Church of England Temperance Society, Junior Section, that a separate Anglican version of the Boys Brigade be created had been rejected by the Brigade's founder, W. A. Smith. As an old Volunteers officer, like Smith, Gee wanted to mobilize schoolboy "playing at soldiers" for the Church of England. On 23 July 1891, he held the first Church Lads Brigade company parade at St Andrew's Church, Fulham, in South London, with the enthusiastic support of the local vicar. One year later there were 118 companies of the new Brigade and Smith's methods of training the young began to permeate England. ${ }^{3}$

The Church Lads Brigade was always at its strongest in the lusher pastures of the South of England, unlike its largely Scottish Presbyterian counterpart : by 1910 there were 1,262 companies in England and Wales and only 9 in Scotland. The majority of Church Lads Brigade

1 Ibid., p. 216.

${ }^{2}$ Cf. Rodney Barker, "The Labour Party and Education for Socialism", in: The International Review of Social History, Vol. XIV, part 1 (1969), pp. 30-31. ${ }^{3}$ Sources for the Church Lads Brigade include: Rev. H. Russell Wakefield, What is the Church Lads Brigade? (London, 1894); F. G. Marshall, St. Mary, Lewisham, Church Lads Brigade: 1892-1929 (London, 1930); Anon., Twentieth Century Souvenir: 1891-1911, a history of the Church Lads Brigade from its foundation (London, 1911); the movement's mouth piece The Brigade, etc. A good modern history of the Church Lads Brigade remains to be written and I hope someday to embark upon such a project in terms of the social history of an institution and its members. 
companies were situated in cathedral cities in the South, although the semi-independent London Diocesan Church Lads Brigade had a large proportion of the total membership. Numbers in the Church Lads Brigade soon drew close to those of the Boys Brigade but both were to find themselves suddenly overtaken by the Boy Scouts in the late 1900 's - a lead which they were never able to recapture. At the time of writing, it would seem that the regimentation, military discipline, and Bible-reading classes that appealed to the 14 to 18 year olds in Edwardian England are no longer in favour. ${ }^{1}$

The Church Lads Brigade was run on strictly hierarchical military lines. Each regimental diocese had several battallions or rural deaneries with a Bishop and a Colonel for each region. Every battallion had a Lieutenant-Colonel and a battallion Chaplain, Captains, AssistantChaplains and Lieutenants. The Church of England was concerned that boys from manual workers' families left Sunday Schools when they left day schools - to find a job at 14 or earlier; it was largely to remedy this lack of social control over working class adolescents that the Church Lads Brigade was set up although in London it appealed more to the sons of skilled artisans than to the non-Church going residuum. A 1911 study of Edwardian boys in a South London area mentioned that only a fifth of working class children actually even attended a Sunday School and that only one per cent of these remained after the age of $14 .^{2}$

From 1905 the Governor of the Church Lads Brigade was an ex-Boer War General, Lord Methuen, followed by Field Marshall Lord Grenfell from 1908 to 1925. There was a Governing Body and an Executive Council which frequently nominated Vice-Presidents. Battallions at grass-roots level had only a very limited say in Brigade affairs through the celebrated Annual Council Conferences. But these Conferences were not really representative of Brigade opinion since the Council comprised the members of the Governing Body, none of whom were

${ }^{1}$ In 1966 an ad hoc committee headed by the Bishop of Exeter, Dr Mortimer, reported on membership in the Church Lads Brigade, which had fallen from 16,245 in 1955 to 11,944 in 1965 . The report said that if the CLB was to remain "an Anglican, uniformed, military-structured, single-sex organization, it would be unrealistic, in the prevailing moral and social climate, to expect it to make a broad-front appeal to boys and to expect any dramatic reversal of existing trends in membership." Quoted in: The Times, 8 December 1966.

2 Alexander Paterson, Across the Bridges: or life by the South London riverside (London, 1911), p. 174. The Sunday School Union confirmed that $80 \%$ of the boys attending Sunday School were lost to the Church between the ages of 14 to 15 , or at the same time as they left day school and entered the labour market. Cf. Arnold Freeman, Boy Life and Labour: The Manufacture of Inefficiency (London, 1914), p. 264. This is a study of working class boys in Birmingham whose subtitle is indicative of a fashionable preoccupation with social darwinism. 
company officers; regimental Colonels and staff officers, who had to be regular or Territorial soldiers; and one Chaplain and one lay officer elected by each battallion. The clergy proved insufficient safeguard against military predominance since there was a great difficulty in finding Chaplains willing to leave their parishes to attend a meeting in London. The lay officer chosen was usually a member of the battallion staff and also a Territorial officer. Consequently, rank and file company officers or chaplains were hardly represented at the Annual Council Conferences, allowing military representatives to more easily gain control of the only really democratic outlet provided for the Church Lads Brigade. This outline of the composition of the Annual Council Conference is included since it was an important factor in determining the degree of participation of the majority of Brigade members in the decision making process and hence in the discussions over their attitude to a dramatic War Office proposal first made in 1909.

The War Office, under Haldane's direction, were trying to organize cadet corps as feeders for the Territorials. The general plan was to absorb all the uniformed youth movements - even those with ostensibly religious goals - into what Haldane called "the big life of national defence". The more training and discipline boys received before they joined the Regular Army, declared Haldane to a cadet audience, the better those fighting units would be. ${ }^{1}$ In 1910 all voluntary youth organizations that gave some form of military instruction (including even the Boy Scouts) were told to apply to their local County Territorial Force Association for official recognition as cadets. But the largely working class Boys Brigade remained aloof and opted to stay out of the War Office scheme by a majority plebiscite of its companies. Their prudent refusal to participate in any alliance with the military and the decision to "cultivate their own garden" was as much a tribute to Smith's determination not to compromise the religious principles upon which the Brigade was founded as it was a triumph for majority opinion within the Brigade. ${ }^{2}$

The Church Lads Brigade offered less resistance to the blandishments of the War Office which was eager to swallow up and militarize the

1 From a speech made by Haldane to the 1st Cadet Battallion of the Queen's Royal West Surrey Regiment on 5 December 1908, quoted in: The Nation in Arms, Vol. IV (Jan., 1909), p. 11.

${ }^{2}$ Smith was "adamant in his refusal to make any compact between the Boys Brigade and the military authorities". R. S. Peacock, Pioneer of Boyhood (Glasgow, 1954), p. 108. Cf. Section on the Boys Brigade and the War Office scheme in my unpublished D.Phil. thesis: Youth and Empire: A study of the propagation of imperialism to the young in Edwardian Britain (Sussex University, 1968), pp. 312-322. 
Edwardian youth movements. Both the Army Council and the Treasury reasoned, on the grounds of financial stringency, that it would be better to run the new national cadet force through the local Territorials to save the War Office the time and expense involved in centralized control. ${ }^{1}$ According to the Army Order issued in 1910, recognition would only be given to a cadet corps which furnished recruits for the Territorials: when cadets reached an age at which enlistment became possible, they would not be allowed to remain in the Brigades unless they joined the Territorials. ${ }^{2}$ This War Office ultimatum had the long term result, if accepted, of virtually depriving the Church youth movements of their religious goals. They were to be compelled by the State either to allow themselves to become recruiting agencies for Haldane's second line of national defence or lose the privileges they already received from the War Office such as: eligibility for a government capitation grant, inspection by uniformed military officers, and the right to hire army camping equipment. ${ }^{3}$

The issue of whether or not the Church Lads Brigade should submit to the Army Council's 1910 Cadet Regulations, or be denied future military and financial assistance from the War Office, led to severe divisions within the movement which were exposed at the subsequent Annual Council Conferences. However, the historian should point out that to some extent these divisions were deceptive since when a draft of these regulations had been issued in 1909, Lord Grenfell had taken the trouble to ascertain from the Archbishop of Canterbury that:

"having in view the possibility if not the probability of Compulsory Training, His Grace was inclined to think that if such conditions as were thought necessary could be obtained, it would be well to take advantage of the scheme, as if Compulsory Training does come, and the Church Lads' Brigade is not recognized it probably would be squashed out."4

1 Cf. Adjutant-General (Hamilton) to Haldane, 23 February 1910 and written comments on by Haldane, 7 March 1910, War Office 32/9 Cadets/227/General Policy; J. N. Murray, Treasury letter to Army Council, 11 August 1910, ibid., 31A. Public Record Office, London.

2 Regulation 15b. From: Regulations Governing the Formation and Administration of Cadet Corps: Draft and offical copy issued with special Army order, provisional (London, HMSO, 1910), War Office Library.

The government also threatened to revive an act of 1819 which would have made it limpossible for any religious organization to carry out military training.

- Minutes of the Church Lads Brigade Governing Body Executive, 20 October 1909, Minute Books, Church Lads Brigade archives, London. 
In effect, the Executive Committee of the Governing Body had already made up its collective mind on the issue and negotiations were opened with the Army Council and the Territorial Associations in 1910 even before the War Office proposals were submitted to local battallions and companies for their approval. ${ }^{1} \mathrm{~A}$ circular issued by the Executive Committee to local officers appeared to prejudge the issue, as well as demanding loyalty and deference to the favourable views expressed towards military training by the Archbishop that were quoted in the pamphlet. The Governing Body did not hesitate to use the clarion calls of "patriotism" and "loyalty" to obtain a majority in favour of recognition. Their circular ended with the resounding hyperbole:

"When patriotism becomes an evil; when loyalty to the King, whom the Church crowns in the House of God, becomes an evil; when resistance to the enemies of King and Country becomes an evil, it will be time for the Church Lads Brigade to lay down its work."2

From 1910 to 1911, at the Church Lads Brigade's Annual Council Conferences, clergymen seeking to prevent their beloved Brigade from becoming a mere auxiliary to the Territorials pointed out, unavailingly, that such a conversion to the War Office line would, in the words of the Vicar of Huddersfield, "make the Church stink in the nostriis of large numbers of the working class". Discussing working class parishes in the North of England, the Vicar went on to inform the assembled Church dignitaries and military men that "it would have been impossible to start or to continue a Church Lads Brigade company in these parishes had it not been understood that there was no intention whatever that Church Lads Brigade companies should be used for the supply of young soldiers for the Territorial regiments."3 This was particularly valid, it was argued, in the parishes of the West Riding of Yorkshire, Durham, Newcastle and the East Midlands: English parishes with noticeably strong working class coal mining communities. According to the Canon of Newcastle, the Northerners were radicals, who hated the spirit of militarism: "there is a strong anti-military

${ }^{1}$ In 1911 The Church Times entered the fray by writing a vigorous leader condemning the action of the Governing Body: "The policy of the Headquarters, in committing the whole Brigade to a momentous change without formally consulting the local branches, was, we are certain, a lamentable error of judgement." The Church Times, 31 March, 1911.

2 Quoted in: The Church Times, 13 April, 1911. The original document does not appear to have survived.

3 Reports of the Annual Council meetings held from 11-12 May, 1911, Special Supplement, in: The Brigade, Vol. XVII, No 7 (July, 1911), p. 8. 
spirit in the North among the masses." 1 This broad, emotional attitude or norm of working class feeling in the North of England goes a long way towards explaining the failure, which was discussed earlier, of the Boy Scouts to recruit from a much broader social base.

The traumatic debate over whether or not the Church Lads Brigade should submit to the Army Council's 1910 Cadet Regulations, which I have only briefly touched upon, polarized the Brigade into North versus South, Clergy versus Military and Governing Body versus Rank and File. With some prominent exceptions, the Colonels were opposed by the Bishops and the State by the Church. What the debate could not conceal completely was that, in line with the legitimated power structure of British youth movements, the ultimate decision had already been taken by the members of the Executive Committee of the Governing Body who were strongly under the influence of the National Service League. There were, in fact, three Anglican Bishops on the National Service League's General Council present at the Brigade's Annual Council Conferences. As one disgruntled correspondent to the Church Times put it, "a military element has captured the Church Lads Brigade" 2

Once the decision had been taken to accept War Office recognition as cadets, contrary to their nearest rival the Boys Brigade, it was not to be reversed until 1936 in Annual Council at Manchester. This meant that for twenty five years, the Church Lads Brigade was under the command of either the County Territorials or the British National Cadet Association, leaving them with little autonomy and few outlets for their primarily religious goals. As a handout on the Brigade has described the change in a classic understatement: "it was at this time that the military uniform and drill of the Brigade, originally adopted for purely symbolic reasons, were given greater meaning and reality than was within the intention of our founders." 3 The involvement of

1 Ibid.

2 The Church Times, 7 April 1911. Prominent clergy in the Church Lads Brigade on the General Council of the National Service League included: Bishop Welldon, the Rev. Russell Wakefield, who was also on the League's executive, the Bishop of Exeter, and the Bishop of Birmingham. Those members of the Brigade who were sympathetic to the League's aims or who had spoken at League meetings in support of conscription included: Lords Methuen and Grenfell, respective Governors of the Brigade, the Bishop of Bath and Wells, on the Governing Body, and Colonel W. M. Gee, the Founder and Secretary of the Brigade. The half a dozen Majors and Major Generals on the Governing Body were even more ardently in favour of military training for the young through exploiting the potential of the Brigade.

${ }^{3}$ Anon., An Historic Note of the Church Lads' Brigade (London, n.d.), n.p. Leaflet in the author's private collection. 
the Church Lads Brigade with Church Scout Patrols, Training Corps, Naval Companies, Cadets and, on the outbreak of war, with the formation of battallions of the King's Royal Rifle Corps, is symptomatic of its over close identification with Britain's national defence: as can be seen by the adoption in $\mathbf{1 9 1 3}$ of Khaki Service Dress Uniform. ${ }^{1}$

\section{IV}

Returning to the main youth movement under discussion - the Boy Scouts Association - an examination of the hierarchical organizational structure of Scouting reveals that it primarily reflected "militarized" patterns of bureaucratic management. As mentioned earlier, in December 1909 the Scout Governing Council and its Executive Committee had been formed, largely, it will become apparent, to prevent the emergence of personality cults associated with either Baden-Powell or Sir Francis Vane. The next links in the chain of office were the County Scout Councils with their County Commissioners and the District Commissioners with their local associations: these were the link between the county command and the local Scoutmaster. In London, for example, there was a District Commissioner, an Executive District Committee, District Councils and local District Committees. The Boy Scouts were organized on a descending scale of national and local hierarchies with committees at every level. But, despite all the superficially democratic machinery of committees, even into the 1920's neither the supreme Governing Council, its Executive Committee nor the local County and District Scout Councils were elected bodies. ${ }^{2}$ Sir Francis Vane also claimed that Scoutmasters' warrants were arbitrarily cancelled, without the right of appeal, as reprisals for any displeasure caused the authorities. As he so cogently put it: "Scouting may have required discipline but it did not need the unthinking obedience of a

1 In 1924 the first blue uniform was adopted as an optional alternative to khaki but in did not become mandatory until 1935.

${ }^{2}$ The lack of a representative London Scout Council in 1909 added much fuel to Vane's charges that Baden-Powell used autocratic methods but when his post of London Commissioner was temporarily abolished by Headquarters, Vane became powerless. To get rid of him, what he dubbed a "militarist clique" had recommended that London be sub-divided into five or seven District Commissionerships focussed under Colonel Ulick de Burgh as Deputy Chief Commissioner. Not surprisingly, General Elles and de Burgh were the authors of this attempt to out-manoeuvre the troublesome Vane whom they found it impossible to work with. Cf. Report by Elles and de Burgh to Baden-Powell, 12 November 1908, British Boy Scouts, Folder 1, Scout Association, London. 
military machine."1 It appears from contemporary testimony as if Baden-Powell used autocratic military methods to govern what was outwardly an educational movement.

It follows on from the above that another aspect of the early history of the Boy Scout movement that Baden-Powell's many hagiographers neglect to give sufficient emphasis to, is that dealing with the internal schisms which came very close to destroying the organization before 1914. Allegations of oligarchy and militarism were continually made against Baden-Powell and his Headquarters staff by dissident leaders of the movement. ${ }^{2}$ Most prominent among the "break-away" groups were: Sir Francis Vane's British Boy Scouts or National Peace Scouts before 1914 and John Hargrave's Kibbo Kift Kindred in the 1920's. ${ }^{3}$ These internecine quarrels were not confined to mere sporadic interruptions in the placid development of Scouting, as most of the existing Scout literature infers: rather they were violent upheavals, as the documentary evidence reveals, which brought into the arena of public debate, and threatened to undermine, the entire power structure and ideology of the movement.

The danger represented by Vane's following within London is sufficiently indicated by the very real fear of Sir Edmund Elles, the Chief Commissioner, early in December 1909, that the entire London membership would withdraw from the Scout movement. Elles told Baden-Powell, rather melodramatically, that the creation of a strong, influential Scout Council and Executive Committee was "the only

1 Vane, "A Danger in the Boy Scout Movement", in: The Westminster Gazette, 1 March 1910, p. 2. A Scoutmaster in Sheffield, who has formed an independent group, claims that expulsions of those who cannot or will not conform to the dictates of association headquarters are still common. The Guardian, 22 May 1971, Letters to the Editor.

${ }^{2}$ Cf. The pamphlets: Captain Noemo [pseudon.],The Boy Scout Bubble (London, 1912), and Vane, The Boy Knight (London, 1910), both attacking militarism in the Boy Scouts. The Managing Secretary, J. A. Kyle, and the Headquarters he represented, were very unpopular among the London Districts. Early in 1909, the Battersea Boy Scouts had broken away to form the original British Boy Scouts. Cf. Kyle to Moore correspondence, May to June 1909, British Boy Scouts, op. cit.

${ }^{3}$ More recently, internal dissensions have reappeared within Scouting proving that this is not a feature peculiar to their past. A traditionalist break-away movement called the Baden-Powell Scouts has been set up to re-instate "the basic ideals and discipline" of old-fashioned Scouting as opposed to the new look, long-trousered image of the central Scout Association which has been accused of encouraging "over-permissive normlessness" (sic) by one District Commissioner. The rebel Scouts display their protest by continuing to wear the short-trousered uniform rejected in 1966 by the Headquarter's Executive Committee as only suitable for the Cubs. The Sunday Times, 9 May 1971. 
thing that can save the movement from disaster. I only fear that it is too late. With such an organization all this would have been impossible - now it is you against Vane." 1 That this particular fear was well grounded is attested to by the evidence of several well-attended protest meetings held in November and December 1909 by London Scoutmasters, braving the threat of instant dismissal, to urge Baden-Powell to reconsider his call for Vane's resignation and to demand far more democratic selection and representation on central Scout committees. ${ }^{2}$ After this structural upheaval, Vane was extruded from the BadenPowell Boy Scouts rather ignominiously to take over the organization of the British Boy Scouts and eventually, because of his bankruptcy and frequent absences abroad organizing the Italian Boy Scouts, he left England completely to start the so-called World Scouts in 1912. What Vane's expulsion cannot conceal is that, in the winter of 1909, Baden-Powell nearly lost the allegiance of his London Boy Scout troops - the fulcrum of the movement.

The First World War was the culmination of Baden-Powell's vision of Scouting as, in the words of a Punch cartoon, "the Youngest Line of Defence for the Empire". ${ }^{3}$ The Chief Scout's own recorded opinions do little to dispel the impression that "a very important motive in the formation of the Scout movement was the defence of the British Empire". ${ }^{3}$ Professor Samuel Hynes has also stressed the role of Scouting in military defence, claiming that "when Baden-Powell organized his Scouting movement he did so with one clear motive - to prepare the next generation of British soldiers. [...] Baden-Powell saw his movement as a preparation for war and the defence of the Empire."4

1 Elles to Baden-Powell, 4 December 1909, British Boy Scouts, op. cit.

2 Protest meetings called by Vane of his "grass-roots" support among London Scoutmasters were held on 16 November 1909 - when the 200 present almost unanimously voted in his favour - and on 3 December at the Caxton Hall, Westminster, when over 300 were present to hear him put his case against the leadership. Reports of the latter were duly presented to Baden-Powell by his "spies" planted in the audience. Earlier, Scoutmasters were considerately supplied by Headquarters with specimen replies to Vane setting out why they refused to attend his meetings: very few co-operated. A motion of confidence in the Chief Scout was carried only with great difficulty at a meeting of the London District Secretaries, held on 22 November 1909, so far had his "credibility gap" widened in the movement.

${ }^{3}$ Punch, 1 September 1909. Bernard Partridge's famous cartoon shows a Boy Scout saying to Mrs. Britannia: "Fear not Gran'ma; no danger can befall you now. Remember $I$ am with you!"

3 W. S. Adams, Edwardian Portraits (London, 1957), p. 137. In avoiding the familiar near idolatry, the section on Baden-Powell in this book tends to verge to the other extreme with a bracing "warts and all" portraiture.

4 Samuel Hynes, The Edwardian Turn of Mind (London, 1968), p. 27. 
Yet Baden-Powell and his Boy Scouts have also to be seen within the context of Edwardian politics and society. As Michael Howard pointed out in 1964, this was a period during which the children of Europe were being trained for a war which was regarded as natural and inevitable. The First World War was "exactly that trial of patriotism, manliness, and endurance for which the nations of Europe had been preparing themselves for an entire generation". ${ }^{1}$ One might speculate that the boys' adventure fiction of G. A. Henty, the 12th Earl of Meath's Empire Day, the Church Lads Brigade and Baden-Powell's Boy Scouts had all made their contributions towards creating that mood of sustained patriotism among the young that led to mass volunteering on the outbreak of war in August 1914. But empircal verification of these influences on the young has so far proved difficult to document unless the statements of the youth leaders themselves are taken at their face value. ${ }^{2}$

The 1914-1918 war gave the para-militarists who were in control of English youth movements a chance to come out into the open after years of disguising their aims beneath the superficial veneer of "woodcraft" or religion. It soon became apparent that Baden-Powell had been training the Boy Scouts for a military role since their inception: the original Scout handbook is chock-full of pronouncements on the necessity for military training in case of a foreign invasion. The large majority of Scoutmasters and senior Rover Scouts (renamed Venture Scouts in 1966) took part in the war as soldiers while those considered to be too young to enlist were encouraged by the movement to act as orderlies, guards, despatch runners and nurses or to give air raid

1 Michael Howard, "Lest We Forget: 'Oh What an Unlovely War...", in: Encounter, Vol. XXII, No 1 (Jan., 1964), p. 64. I am grateful to my colleague Dr Michael Ekstein for drawing my attention to this essay. Cf. Roy Douglas, "Voluntary Enlistment in the First World War and the Work of the Parliamentary Recruiting Committee", in: The Journal of Modern History, Vol. 42, No 4 (Dec., 1970), pp. 564-585.

2 The Earl of Meath, for example, claimed that his Empire Day Movement "was not without effect on the successful prosecution of the world war in defence of liberty and justice" and that "a large proportion of those young men from all parts of the Empire, who rushed to the Colours during the bloody years from 1914, must have learnt at school the watch-words of the Movement." Quoted in: The Times, 24 May 1921. Cf. my articles on: "The Rise and Fall of Henty's Empire", in: The Times Literary Supplement, 3 October 1968, and "Lord Meath, Youth and Empire", in: The Journal of Contemporary History, Vol. 5, No $4,(1970)$, pp. 97-111. These are attempts to examine socio-cultural aspects of British "imperialism" which remain relatively unexplored by historians and, together with this article, will eventually form the basis for a much wider study. 
warnings. ${ }^{1}$ At Kitchener's request, the Sea Scouts acted as auxiliary coastguards and, according to Baden-Powell, they formed "an integral part of the machinery of national defence". ${ }^{2}$ It is worthy of note that a whole chapter in The Times History of the War is devoted to the Boy Scout contribution to the war effort. ${ }^{3}$ Even such an unlikely authority as Paul Wilkinson argues that socialization within the Boy Scouts helped to maintain the middle-class value systems inculcated into the British soldier :

"It is no exaggeration to say that Kitchener's New Army depended on boy-scout spirit and resourcefulness for its morale, and on the dissemination of public school loyalties and values among lower middle-class and working-class men. This had been, to a large extent, accomplished by the patriotic youth movements. As a result, loyalty among volunteers and conscripts alike withstood even the criminal negligence of the generalship in that war, though inevitably it wilted as the terrible cost in life mounted."4

Another of Baden-Powell's war time schemes, demonstrating the smooth transformation of Scouting from a "woodcraft" to a "paramilitary" organization, was the aptly titled Scouts Defence Corps. The corps manual Marksmanship for Boys stated their object as being to "form a trained force of young men who would be immediately available for the defence of the country should their services be required during the war." 5 About 7,000 Scouts, all under 17, were submitted to a rigorous training aimed at creating an efficient fighting man; a "red" feather was awarded to Boy Scouts who passed the recruiting tests which included rifle-shooting and military drill. In 1915, when there was a chance that age and measurement standards for enlistment might

1 The Kent County Commissioner rhapsodised that the Boy Scouts under his command had "stimulated recruiting for the Army, hunted out Germans, manned several coastguard stations, [and] accounted for a good many spies; in one case they reported an aeroplane to a fort and had it stopped" (sic). Despite all this interference, he was gratified to report that they had won "golden opinions" from all with whom they came into contact. Quoted in: E. K. Wade, Twenty One Years of Scouting (London, 1929), p. 181.

2 Baden-Powell, Guarding the Coasts of Britain: What the Sea Scouts are Doing (London, 1918), p. 6.

3 The Times History of the War (London, 1919), Vol. XVII, chap. ccliii. This chapter is, however, careful to defend Scouting against possible charges of Germanic "militarism". Cf. Anon., Boy Scouts and the Great War. (London, 1915).

4 Wilkinson, op. cit., p. 23.

5 Baden-Powell, Marksmanship for Boys: the Red Feather and How to Win It (London, 1915), p. 62. 
be lowered if the war continued, Scout leaders advocated sending these boys to the Front as reinforcements with great alacrity. ${ }^{1}$ For the retired soldiers of Baden-Powell's generation, the First World War was the ultimate testing ground for all the British youth movements that gave some form of military training. For example, the cadets of the Church Lads Brigade Training Corps, affiliated to the King's Royal Rifle Corps, raised two battallions of ex-members to fight in France while the ill-fated 16th Highland Light Infantry, raised entirely from former members of the Glasgow Boys Brigade, was decimated on the Somme. ${ }^{2}$ Some 150,000 ex-Boy Scouts served in the Forces and 10,000 odd were killed in action; 80,000 earned their War Service badges and 25,000 their coast-watching badges; 11 VC's were awarded to ex-Scouts including the famous Jack Cornwell at the Battle of Jutland. ${ }^{3}$ Little wonder then, that generals like Sir Ian Hamilton believed that only the fear of invoking cries of militarism made the leaders of British youth movements wary to declare their direct interest in compulsory military training for boys before the outbreak of war. They were really using religion or Scouting, he alleged percipiently in 1912, as bait to turn boys into soldiers but were afraid to come out into the open about their motives for training the young. ${ }^{4}$

Not long after Scouting's "finest hour" during the First World War, there came a recrudescence of the threat to the movement's stability represented by internal dissidence, only this time it came from a leftwing idealist rather than from a liberal aristocrat. John Hargrave, the undoubtedly charismatic Headquarters' Commisioner for Camping and Woodcraft, had served as a stretcher bearer during the war as he came from a Quaker family but he had been invalided out in September 1916. He returned to England to all appearances marked out as BadenPowell's eventual successor but found to his dismay that Scouting was

1 Cf. The Boy Scouts Association, Executive Committee, Sixth Annual Report (1915), pp. xvii-xviii, British Museum. Several Scout troops did, in fact, enlist having received previous training in the Defence Corps which, we are told, enabled them to win rapid promotion from 1916 to 1918. In 1914 the average age of the Boy Scout was 15 and only $40 \%$ of the Scouts were from 14 to 19 years old, compared with over $70 \%$ in the Boys Brigade.

${ }^{2}$ Cf. Martin Middlebrook, The First Day on the Somme (London, 1971), pp. 10 , $14,217,236$.

${ }^{3}$ Sources for these figures: Cf. The Times, 31 January 1919; Evans, op. cit., p. 37; D. H. Macartney, Boy Welfare (London, 1917), p. 39.

4 Ian Hamilton, National Life and National Training (London, 1913), pp. 19-22. This pamphlet was based upon an address delivered in the Central Hall, Birmingham, on 24 September 1912. The publisher's blurb advertised it as a "stirring plea for the universal military training of boys". Hamilton was AdjutantGeneral when the Army Council's Cadet Regulations were first published in 1910. 
being used by the militarists as an instrument for war. The rebellious Commissioner wanted the Royal Charter of 1912 torn up and the Endowment Fund reconsidered since they prevented the movement from being democratically organized, and all imperialistic and military passages deleted from the official handbook. Like Vane, he maintained that the Boy Scout Governing Council was a "military cabal" controlling a great educational movement. By advocating the woodcraft ideas of Ernest Thompson Seton against the ultra-patriotism of the ruling military élite that controlled the Boy Scouts, Hargrave soon came into serious conflict with Baden-Powell.

In February 1920, Hargrave's name was taken off the staff list of Headquarters' Commissioners published in the Headquarters Gazette and on 13 January 1921 his warrants as an Assistant District Commissioner and Scoutmaster were cancelled. The London Scout Council also passed a resolution by 34 votes to 30 , on 24 January 1921, preventing Hargrave from speaking at any Scout meeting in London or from publishing any further articles in any Scout magazine. ${ }^{1}$ After being abruptly ejected from the Boy Scouts, Hargrave commenced to organize his Kibbo Kift Kindred version of scouting which, although it was seen by many South London Labour and Co-operative youth groups as a left-wing alternative to the Boy Scouts, soon dispersed its energies and momentum in sectarian quarrels. ${ }^{2}$

"White Fox", as Hargrave preferred to be known, was expelled from the mainstream Scout movement not, as some have suggested, because of the overtones of pantheism in his woodcraft ideas but for a series of articles attacking the ideology of Scouting that appeared in The Trail: the official organ of the London Scout Council. Using Baden-Powell's Scouting for Boys as his basic data, he concluded that not only was the movement "party political" along Tory imperialist lines but that there was a basic division between its ideas of woodcraft internationalism and its espousal of patriotic jingoism based upon force. ${ }^{3}$ Almost

1 Cf. Annual General Meeting of the London Scout Council, in: The Trail, Vol. IV, No 37 (Febr., 1921), pp. 49-50.

2 Hargrave was one of the main formative influences on the German Bünde in the 1920's. For his later career in the 1930's as an exponent of Social Credit and the fascist Green Shirt movement, see: J. L. Finlay, "John Hargrave, the Green Shirts, and Social Credit", in: The Journal of Contemporary History, Vol. 5, No 1 (1970), pp. 53-71. For information on the histories of the small woodcraft movements of the 1920's, such as the Order of Woodcraft Chivalry, the Kibbo Kift Kindred and the Woodcraft Folk, see: Leslie Allen, The Republic of Children (London, 1938); Leslie Paul, The Folk Trail (London, 1929); and I. O. Evans, Woodcraft and World Service (London, 1930). All of these movements produced their own cyclostyled literature.

${ }^{3}$ Cf. Hargrave, "The Words of White Fox", in: The Trail, Vol. III (Sept., 1920), 
half a century later, an American academic was to repeat the accusation that Scouting for Boys was "a crude and insistent expression of the Tory imperialism that provided the motivation for the movement". 1 Plus ça change, plus c'est la même chose.

The ejection of vociferous anti-militarists and pacifists from the Boy Scouts, although admittedly partly exacerbated by their rampant egotism, served to emphasize even further the autocratic, hierarchical power structure of Baden-Powell's creation. An analysis of the history of British youth movements before 1930 reveals as a pronounced feature a constant interplay between justifying symbols, institutional authorities and the concept of "obedience". Accordingly, the political relevance of cultural code symbols, ${ }^{2}$ such as "loyalty", "patriotism" and "good citizenship", was made explicit in their manipulation by Baden-Powell (and by the Governing Body of the Church Lads Brigade), in order to justify adherence or opposition to the arrangement of power within the hierarchy. The anti-militarists, with Vane, Thompson Seton and Hargrave as the most prominent personalities among them, were thrown out of Baden-Powell's movement because, by opposing the master symbols of legitimation, ${ }^{3}$ they were revealed as trouble makers who rejected linguistic penalties and thence the leadership imposed from above by the ruling élite.

p. 272, and "What I'm Driving At" (Nov., 1920), pp. 353-354, which concluded that Scouting was still "very strongly political on the Imperial side" and backed by people who are "naturally anxious to keep the Scout movement very distinctly imperialistic in its methods of training British boys". Hargrave also wrote an article on: "The Demilitarization of the Scout Movement", in: Foreign Affairs, Vol. II (August, 1920), pp. 26-27. Among the members of the Advisory Council of The Trail (which became a Kibbo Kift publication) were Norman Angell, Havelock Ellis, Maeterlinck, Romain Rolland and Anatole France.

i Samuel Hynes, op cit., p. 27.

2 The concept of "cultural codes" used briefly out of context here can be found more fully developed in the works of Claude Lévi-Strauss. Cf. Lévi-Strauss, Totemism (London, Penguin ed., 1969), particularly the introduction by Roger C. Poole; Edmund Leach, Levi-Strauss (London, 1970); Lévi-Strauss, La Pensée Sauvage (Paris, 1962); tr., The Savage Mind (London, 1966).

${ }^{3} \mathrm{C}$. Wright Mills believed that "the relation of such symbols to the structure of institutions" was "amongst the most important problems of social science". Wright Mills, The Sociological Imagination (London, Penguin ed., 1959), p. 37. Although, as David J. Rothman has pointed out, the historian's task is to test and even to formulate theory rather than to search for examples that coincide neatly with sociological constructs. Cf. Rothman, "Sociology and History", in: Past and Present, No 52 (August, 1971), p. 132. 
These self-styled "rebels" were labelled by the Chief Scout, using the armoury of legitimated invective at his disposal, as "disloyal", "unpatriotic", "disobedient" or, as in Hargrave's case, accused of "Socialistic and bolshevik tendencies". 1 Thus the military élite that ran the Boy Scouts disciplined its ideological deviants by strategically pre-empting certain approved norms of middle-class Edwardian society, as expressed in coded symbolic language, to Scouting orthodoxy before these highly emotive terms of cultural disapproval could be taken over and used against them by their opponents. Similarly, the dissident clergy within the Church Lads Brigade, who quixotically objected to their becoming part of a national defence force, were frequently accused of a lack of "discipline", of "disloyalty" or even of being "unpatriotic" by the militarists on the Governing Body.

It should have become clear, from the preceding analysis, that there are several basic differences in interpretation and emphasis between this account of British youth movements from 1908 to 1930 and that given in earlier authorised works seeking to justify the "tone" and direction of these organizations. While they, broadly speaking, see Scouting and the Church Lads Brigade as remaining somehow politically inviolate, the historical evidence would seem to point to manipulation by the National Service League and, when current research in progress on the latter reaches fruition, it is to be hoped that this connection will become much clearer. ${ }^{2}$ While much previous writing on youth movements places Scouting securely at the "liberal" centre of the British political spectrum, it is clear from both internal and external criticism that it was too often identified with insular patriotism, militarism and Tory imperialism for this to be an accurate label. Equally, Baden-Powell's "firm anti-bolshevism" was more a symptom of his near paranoid divergence from the main-stream of English political life than an expression of "the views of the great mass of steady-going citizens". ${ }^{3}$

What seems to be conspicuously lacking from earlier accounts of

${ }^{1}$ Cf. Annual General Meeting of the London Scout Council, loc. cit., p. 50.

2 As far as I have been able to ascertain, research into the history of the National Service League is at present being conducted by: Michael Allison of St Osyth's College, Essex, and James Rosenbloom of the University of California (Berkeley), America. There was probably no other pre-war propaganda organization which permeated the social life of England to the same extent as the National Service League. But of the $130 \mathrm{MP}$ 's who favoured the League in the 1910 House of Commons, of those whose names were published, 102 were Conservative Unionists and only 3 were Liberals. Working class support was minimal: cf. Stephen Reynolds, Seems So! A Working Class View of Politics (London, 1911), p. 82. 3 Wilkinson, op. cit., p. 16. For Baden-Powell's exaggerated fears of "bolshevism" see: W. S. Adams, op. cit., p. 142. 
British youth movements is any attempt to put into practice the dictum that no historian can afford to ignore the process whereby power translates itself into political activity. Some attempt has been made here to correct the balance by looking more closely at the structures of power and influence within the Boy Scouts Association and the Church Lads Brigade in the heyday of their popularity. A tentative surmise would be that the leaders of these youth movements were put under heavy political pressure before 1914, by the National Service League and the War Office, to allow their various forms of training to become vehicles for the militarization of the young and platforms for adult political "protest" against the absence of compulsory military training for boys in Britain.

After the comparative failure of the Earl of Meath's Lads Drill Association, founded in 1899, and of the cadet clauses in Haldane's 1907 Territorial Bill - defeated by 190 votes in the House of Commons the National Service League, according to the scenario of the antimilitarists, switched its tactics and took over the youth movements in order to try and produce a national cadet force by more devious methods. ${ }^{1}$ The conversion of the Church Lads Brigade in 1911 from a basically religious into a basically military movement would seem to bear out this thesis; but mucr more work needs to be done from Scout and Brigade archives on the degree of informal political control exercised by the National Service League over the executive committees on which it was represented in the youth movements, before any firm conclusions can be drawn from what little documentary evidence of the League's own activities seems to have survived. Nevertheless, the political and military intersections of the leaders of a movement like the Boy Scouts with the Tory Party, the Territorials, the Army, Tariff Reform and the National Service League would seem to lend validity to a contention that British youth in the Edwardian era found is energies harnessed only to causes approved of by adult leadership: foremost among which were imperial and national defence. ${ }^{2}$ Scouting may have been carefully designed to respond to the needs and demands of the young but its normative content was much more overtly political than educational.

Basic to this contribution to the debate over the early history of

1 Cf. Vane, The Boy Knight, op. cit., p. 14.

although it could be argued that there were a limited number of Edwardian "patriots" who were prepared to give up their time, money and energy for such causes it would seem to me that this interlocking power élite shared both a common military ideology and social background which together gave shape to the Boy Scout movement. 
British youth movements is the implicit suggestion that a more useful way of looking at their origins than that employed by their erstwhile apologists, is to see them as a form of social control exercised over the young by a collection of ex-soldiers and imperialists who were anxious to mobilize them in a military direction. This interpretation may have given more weight to the "political" goals of British youth movements than is usually thought desirable but this imbalance is the price to be paid for any attempt at readjusting historical boundaries and is not meant to be read as a definitive study of what has been termed "the complex and subtle inter-generational dialectic of pressure, response, leadership and collaboration". ${ }^{1}$ But it is worth emphasizing that this "dialectic" has to be seen constantly within the super-structure and distribution of power of these movements and as only one element in the process of historical change which shaped their careers.

Thus, in understanding the crucial failure of the Boy Scouts to capture the vast numbers of un-organized working class youth, the historian has to take into account not only the financial obstacles to their membership but also the Tory imperialist ideology permeating Scouting even, according to left-wing critics like Hargrave, during the inter-war years. It is important, from this stand-point, to remember that the institutionalized social education of the young before, and for some time after, the First World War rested largely in the hands of middleaged, middle-class, ex-Army officers. In serving to propagate their nationalist military ideologies, youth movements acted as an instrument for the transmission of the norms and values of one generation to that of the next. By re-directing and absorbing the demands of the young, the militarists ensured that the propaganda of the National Service League and others like it, did not fall entirely on fallow ground. "Otherwise it is difficult to understand", wrote Caroline Playne in 1928, about a problem which has puzzled commentators ever since, "how it came about that practically the whole of youth rushed with blind nobility, but absolute heedlessness of causes, into the arena of war at the first moment possible."2

1 Wilkinson, op. cit., p. 4.

2 Caroline E. Playne, The Pre-War Mind in Britain (London, 1928), p. 162. 